Note

\title{
Accumulation of Paralytic Shellfish Poison (PSP) and Biotransformation of Its Components in Oysters Crassostrea gigas Fed with the Toxic Dinoflagellate Alexandrium tamarense
}

(Received March 16, 2005)

\author{
Manabu Asakawa*1, ${ }^{\dagger}$, Rieko Beppu*1, Katsutoshi Ito*1, Makiko Tsubota*1, \\ Haruyoshi TAKAyama*2 and Keisuke Miyazawa*1 \\ (*1 Department of Bioresource Science and Technology, Graduate School of Biosphere Science, \\ Hiroshima University: 1-4-4, Kagamiyama, Higashi-Hiroshima, Hiroshima 739-8528, Japan; \\ *2 Hiroshima Prefectural Fisheries \& Marine Technology Center: Ondo, Kure, \\ Hiroshima 737-1207, Japan; ${ }^{\dagger}$ Corresponding author)
}

As a part of our studies on the mechanism of uptake of paralytic shellfish poison (PSP) and the kinetics of its accumulation in bivalves, oysters Crassostrea gigas were experimentally contaminated with PSP by being fed with the toxic dinoflagellate Alexandrium tamarense for 2, 4, 6, 8 and 10 days. Temporal variations in the PSP contents and their profiles in oysters during the feeding experiment were monitored by high-performance liquid chromatography (HPLC) and the toxin profile of the oysters was compared with that of $A$. tamarense. Toxins excreted from the infested oysters into the seawater for 2 and 10 days were recovered and analyzed by HPLC. PSP toxicity rapidly appeared in the tissues of oysters and their toxicity levels reached $0.6(0.3), 2.2$ (1.1), $1.0(0.5), 3.4(1.6)$ and $1.1(0.5) \mathrm{MU} / \mathrm{g}(\mathrm{nmol} / \mathrm{g})$ shucked meat at 2, 4, 6, 8 and 10 days, respectively. The accumulation rates of toxin, calculated from the total amount (nmol) of toxins expressed by the total cell number fed during the exposure period and the toxicity of the oysters, were $14.1,18.7,5.1,14.9$ and $3.2 \%$ for $2,4,6,8$ and 10 days. During feeding experiments, the toxin profile of oysters changed substantially, showing marked differences from the proportions found in the toxigenic dinoflagellate used as food. The toxin components in this strain existed almost exclusively as $\beta$-epimers, which accounted for $66.3 \mathrm{~mol} \%$ of the total. This contrasts with the case of the oysters, where the $\beta$-epimers represented $24.8,29.8,25.1,27.3$ and $25.2 \mathrm{~mol} \%$ of the total at $2,4,6,8$ and 10 days, respectively. The amount of gonyautoxin-1 (GTX1) accumulated in oysters increased linearly and slowly for 8 days and the maximum content of GTX1 reached 51.3 mol\%. The composition of GTX group compounds recovered from the seawater in which the oysters had been reared was a little different from that within the oyster tissues.

Key words: paralytic shellfish poison; Alexandrium tamarense; Hiroshima Bay; dinoflagellate; oyster; gonyautoxin; saxitoxin

\section{Introduction}

PSP (paralytic shellfish poison) is produced by a number of toxic dinoflagellate species, such as Alexandrium tamarense, A. catenella, Gymnodinium catenatum and Pyrodinium bahamense var. compressum. These molecules, of which the most potent representative is saxitoxin (STX), are a class of neurotoxic alkaloids having different isoforms and various degrees of toxicity. To date more than 20 STX analogues have been reported ${ }^{11}$. These toxins, which selectively block voltage-gated $\mathrm{Na}^{+}$channels in excitable membranes, can be accumulated in filter-feeding shellfish that feed on the dinoflagellates, resulting in illness at higher trophic levels in the food chain. The main symptoms in humans are paralysis in parts of the body, followed by death in severe cases ${ }^{2}$. Hence, PSP potentially threatens human health, shellfish culture and related industries worldwide. The oyster Crassostrea gigas is one of the most edible important bivalves and has been cultivated on a large scale in several areas of Japan for a long time. Since cultured oysters produced in Hiroshima Bay, Hiroshima Prefecture are shipped to many areas in Japan not only as fresh oysters, but also as raw materials for processed foods such as smoked oyster, oyster sauce, etc., toxification of oysters posed very serious problems to fishermen and workers in associated industries, as well as to public health. The first PSP infestation of shellfish in Hiroshima Bay, which is one of the largest oyster culture areas in Japan, 
was reported in 19923), 4). Since that episode, bivalves have been contaminated with PSP almost every year. We also reported that in the 1993-2004 survey on the occurrence of PSP-producing dinoflagellates in Hiroshima Bay, five strains of $A$. tamarense were isolated, and their PSP profiles were investigated ${ }^{5)}$. Differences not only in toxicity among various species of shellfish collected from the same area, but also in toxin profiles between causative organisms and infested shellfish have been recognized. Although accumulation of PSP in bivalves correlates with that of toxic dinoflagellate blooms, bivalves frequently contain a higher proportion of carbamate toxins (or a lower proportion of $N$ sulfocarbamoyl toxins) in comparison with the causative dinoflagellates ${ }^{3-9)}$. Differences of toxin profile between bivalves and the responsible dinoflagellates might be explained in terms of toxin-specific uptake or elimination, or enzymatic and/or chemical transformation of toxins after accumulation in bivalve tissues ${ }^{10)-13)}$. However, the mechanisms of toxin uptake and bioconversion in bivalves and the fate of toxins during and after accumulation remain largely unknown. From a food hygienic point of view, it is necessary to elucidate the mechanisms of PSP infestation in bivalves and related phenomena. In a previous paper, short-necked clams were experimentally contaminated with PSP by being fed with $A$. tamarense, and the processes of PSP accumulation and bioconversion were investigated in terms of toxicity level and toxin components ${ }^{6}$. In the present study, we investigated the biotransformations between toxin types in oysters. The behavior of toxins in oysters was examined by feeding cultured toxic dinoflagellate $A$. tamarense for 2, 4, 6, 8 and 10 days, and the process of PSP accumulation and temporal changes of toxin content and composition in oysters were investigated by mouse bioassay and high-performance liquid chromatography (HPLC).

\section{Materials and Methods}

\section{Dinoflagellates}

Strain ATHS-92 of the toxigenic dinoflagellate Alexandrium tamarense used in this study was isolated from Hiroshima Bay in April 1992. The strain was cultured batchwise in modified SW-II medium at $15^{\circ} \mathrm{C}$ under a light intensity of $400 \mu \mathrm{E} / \mathrm{m}^{2} \mathrm{~s}(12: 12 \mathrm{hr} \mathrm{LD}$ cycle $)^{4)-6)}$. Algal cells of this toxic species were used in the exponential growth phase.

Contamination of oysters with PSP by feeding with A. tamarense

Non-toxic cultured oysters Crassostrea gigas were collected near the city of Etajima, Noumijima Island, which is located almost at the center of Hiroshima Bay, in October 1999, and checked for the absence of PSP by means of HPLC analysis as described below. They were acclimated to the experimental conditions for 3 days in a flow-through system using filtered ambient seawater at $18^{\circ} \mathrm{C}$ with continuous aeration under a $12: 12 \mathrm{hr} \mathrm{L} / \mathrm{D}$ cycle until the beginning of the feeding experiments.
They were divided into five identical transparent plastic pails (12 oysters per pail) filled with $20 \mathrm{~L}$ of aerated and filtered seawater at $18^{\circ} \mathrm{C}$. Oysters in pails No. $1-5$ were fed on $A$. tamarense cells by addition of $250 \mathrm{~mL}$ of the culture containing $34.1 \pm 5.4$ (mean \pm S.D., $n=10) \times$ $10^{5}$ cells at 10 am every day. Total supplied cell numbers were $60,129,194,271$ and $341 \times 10^{5}$ cells for $2,4,6$, 8 and 10 days, respectively. Cell numbers were counted before and after adding the culture of $A$. tamarense to the pail. After completion of these feeding experiments, all samples were removed and shucked. The toxicity of tissues was determined by mouse bioassay based on the Japanese official method ${ }^{14)}$. The cell numbers filtered by the oysters were estimated by counting after the bivalves had been removed. Weighed whole tissues of 12 oysters in each group were combined and frozen immediately at $-80^{\circ} \mathrm{C}$ until toxins were extracted as described below.

\section{Recovery of toxins from seawater}

After 2 and 10 days of feeding, the seawater (ca. $20 \mathrm{~L}$ ) in which the oysters had been reared was passed through a $0.45 \mu \mathrm{m}$ membrane filter. Faecal material and remaining $A$. tamarense cells in the seawater were recovered on a filter and subjected to toxicity assay. The filtrate ( $c a .20 \mathrm{~L}$ ) was evaporated to $c a .3 \mathrm{~L}$, adjusted to $\mathrm{pH} 5.5$ with $0.1 \mathrm{~mol} / \mathrm{L}$ acetic acid, and loaded onto a glass column $(5 \mathrm{~cm}$ i.d. $\times 40 \mathrm{~cm})$ packed with activated charcoal (Wako, Tokyo, Japan). The column was washed with distilled water, then toxins were eluted with $20 \%$ ethanol containing $1 \%$ acetic acid, concentrated by evaporation, and dissolved in $0.1 \mathrm{~mol} / \mathrm{L}$ acetic acid. The toxicity of this fraction was measured by bioassay using male mice as described below. An aliquot $(0.5 \mathrm{~mL})$ of this solution was subjected to ultrafiltration on a Microcon YM-3 centrifugal filter device (Millipore) and centrifuged at $5,000 \times g$ for $10 \mathrm{~min}$. The filtrate was subjected to toxin determination as described below.

\section{Assay of toxicity}

In the toxicity assay of the dinoflagellates, cells harvested by rotation at 3,000 rpm for $10 \mathrm{~min}$ were suspended in $0.5 \mathrm{~mol} / \mathrm{L}$ acetic acid and ultrasonicated for $10 \mathrm{~min}$. The lysate was centrifuged and the supernatant was diluted appropriately with water, then assayed for toxicity by an official Japanese method ${ }^{14)}$. The toxicity was expressed in mouse units (MU); $1.0 \mathrm{MU}$ is defined as the dose of toxin required to kill a 19-21g ddY strain male mouse in 15 min after intraperitoneal injection. The PSP toxicity of the shellfish samples was measured by the ame method. Toxicities of faeces and residual $A$. tamarense cells in the seawater that had been used to rear the oysters were examined by the same method mentioned above.

Purification of toxins from A. tamarense cells and bivalves Extraction and purification of toxins from cultured $A$. tamarense cells and whole shucked oyster tissues were 
carried out according to essentially the same method as described before ${ }^{3), 4)}$. An aliquot of the culture of A. tamarense was transferred to a glass vial and centrifuged at 3,000 rpm for $10 \mathrm{~min}$. The supernatant was removed, and toxins in the cells were extracted with $0.5 \mathrm{~mol} / \mathrm{L}$ acetic acid by ultrasonication. This acetic acid extract was concentrated and loaded on a Sep-Pak Plus C18 Environmental Cartridge (Waters). The unbound portion was collected and concentrated to dryness in vacuo. The residue was dissolved in a small amount of distilled water and injected into the HPLCfluorometric system. Toxins from the toxic specimens of oysters were partially purified essentially according to the procedures described previously ${ }^{6}$.

\section{HPLC analysis of PSP compositions}

Analysis of PSP toxins by HPLC was carried out by the method described previously ${ }^{5), 6)}$. The PSP toxin contents in the samples were determined by comparing the peak areas of each toxin with those of the standards. Contents of N-sulfocarbamoyl derivatives (C1(PX1 or epi-GTX8)), C2 (PX2 or GTX8), C3 (PX3), C4 (PX4), GTX 5 (B1) and GTX6 (B2)) were estimated from the increased amounts of corresponding carbamate toxins (GTX 2, 3, 1, 4, STX and neoSTX) after treatment with $0.1 \mathrm{~mol} / \mathrm{L}$ hydrochloric acid for $15 \mathrm{~min}$ in boiling water. PSP compositions were expressed as mol\% of each toxin component ${ }^{15)}$.

\section{Results and Discussion}

In this feeding experiment, the strain $A$. tamarense (ATHS-92) possessed a specific toxicity of $79.4 \pm 31.6$ (mean \pm S.D., $n=5) \times 10^{-6} \mathrm{MU} /$ cell. Total toxin concentration of this strain was $61.4 \pm 24.5$ (mean \pm S.D., $n=5$ ) $\mathrm{fmol} / \mathrm{cell}$. The relative amounts of individual toxins contained in $A$. tamarense cells were fairly constant throughout the experimental feeding period. PSP components produced are partially transformed in the oysters, as in other bivalves. Figure 1 shows the amount of toxins accumulated in oysters fed with $A$. tamarense and the seawater in which oysters had been kept during the feeding experiments. PSP toxicity rapidly appeared in the tissues of oysters, and the toxicity levels reached 0.6 (0.3), 2.2 (1.1), 1.0 (0.5), 3.4 (1.6) and 1.1 (0.5) MU/g $(\mathrm{nmol} / \mathrm{g})$ shucked meat after 2, 4, 6, 8 and 10 days of feeding, respectively. The amount of toxin in oysters did not increase in parallel with the abundance of $A$. tamarense cells supplied during feeding. The toxicities of the oysters fed with A. tamarense for 6 and 10 days were lower than those of the other experimental groups.

Table 1 shows the balance of toxicities supplied to and recovered in oysters and seawater in which they had been reared, after the feeding experiments for 2 and 10 days. The toxin accumulation in the oysters was much lower than that supplied by $A$. tamarense. This low level of toxin accumulation is thought to be due to low uptake of cells by oysters. It is generally accepted that when bivalves are exposed to high densities of toxic dinoflagellates, the rate of toxin uptake decreases

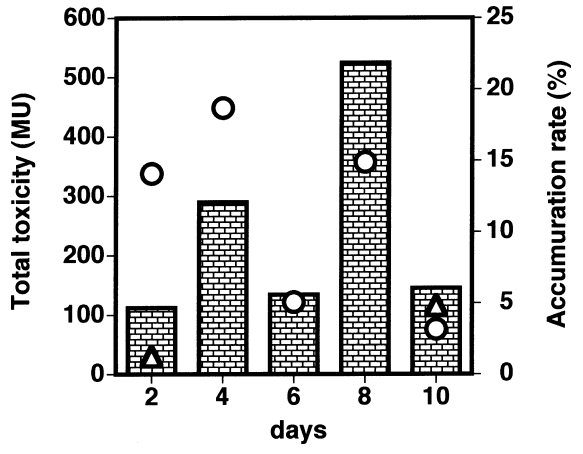

Fig. 1. Toxicity and accumulation rate of PSP toxins in oysters fed with Alexandrium tamarense cells

口 Total toxicity of shucked whole meat from 12 oysters

$\Delta$ Total toxicty recovered from the seawater in which oysters were fed with $A$. tamarense cells

O Accumulation rate (\%) of toxins

Table 1. Balance of Toxicity between Supplied Alexandrium tamarense Cells, Oysters Fed with $A$. tamarense Cells, Rearing Seawater in which the Oysters were Kept and Residual A. tamarense Cells in the Seawater

\begin{tabular}{ccccc}
\hline \hline \multirow{2}{*}{$\begin{array}{c}\text { Feeding } \\
\text { period } \\
\text { (day) }\end{array}$} & A. tamarens & Oyster* & Seawater* & $\begin{array}{c}\text { Residual } \\
\text { A. tamarense* }\end{array}$ \\
\cline { 2 - 5 } & 476 & 112 & 30 & 26 \\
2 & 2,710 & 149 & 116 & 11 \\
\hline
\end{tabular}

Toxicity is expressed in terms of mouse unit (MU).

* Sampling at the next day morning after feeding with A. tamarense cell

owing to a reduction in filter feeding or direct exclusion of cells ${ }^{16)}$. However, the clearance rates of $A$. tamarense cells by oysters were calculated to be 94.5, 98.8, 99.1, 99.7 and $99.6 \%$ over 2, 4, 6, 8 and 10 days in the feeding experiments, indicating that the oysters actively ingested $A$. tamarense cells in this study. The absence of toxicity in faeces also indicated a low level of direct exclusion of cells by the oysters. As shown in Fig. 1, the accumulation rate of PSP toxins, which is the ratio of toxin amount accumulated in oysters to that of $A$. tamarense cells ingested by oysters, was very low in each experimental group. This means that the toxins once accumulated in oysters are removed via some pathways, as indicated by several previous reports ${ }^{17), 18)}$. To clarify this, the toxicities of the seawater in which the oysters had been kept and residual $A$. tamarense cells were then examined. As shown in Table 1, release of toxin from contaminated oysters clearly occurred. However, it was not sufficient to account for the low accumulation rate. On the other hand, the results shown in Table 1 indicate that the percentage $(35.3 \%$ and $10.2 \%$ for 2 and 10 days of feeding, respectively) recovery of toxins from oysters, seawater and residual $A$. tamarense cells was remarkable low. This indicates that 
Table 2. Toxin Profiles of Alexandrium tamarense and Oysters Fed with A. tamarense

\begin{tabular}{|c|c|c|c|c|c|c|}
\hline \multirow{2}{*}{$\begin{array}{c}\text { PSP } \\
\text { components }\end{array}$} & \multirow{2}{*}{ A. tamarense } & \multicolumn{5}{|c|}{ Oysters fed with $A$. tamarense } \\
\hline & & 2 days & 4 days & 6 days & 8 days & 10 days \\
\hline GTX1 & 18.7 & 32.0 & 41.2 & 46.7 & 51.3 & 41.9 \\
\hline GTX2 & 0.5 & 1.6 & 3.1 & 2.7 & 4.3 & 3.4 \\
\hline GTX3 & 2.1 & 1.6 & 3.1 & 2.7 & 3.4 & 2.9 \\
\hline GTX4 & 34.2 & 20.8 & 21.3 & 22.4 & 22.2 & 22.3 \\
\hline $\mathrm{C} 1(\mathrm{PX} 1)$ & 8.7 & 1.6 & 5.3 & 0 & 2.1 & 0 \\
\hline C2(PX2) & 30.0 & 2.4 & 5.4 & 0 & 1.7 & 0 \\
\hline C3(PX3) & 1.3 & 0 & 0 & 0 & 0 & 0 \\
\hline neoSTX & 4.5 & 40.0 & 20.6 & 24.9 & 14.7 & 28.5 \\
\hline STX & 0 & 0 & 0 & 0.6 & 0.3 & 1.0 \\
\hline
\end{tabular}

All results are shown in mol\%.

most of the supplied toxins disappeared from the experimental system. The reason for this is presumably decomposition of the toxins in oysters and seawater. The level of toxification of oysters may depend on the levels of these decomposition activities.

Table 2 shows the toxin profile of the cultured cells of $A$. tamarense and the oysters fed with this dinoflagellate. Predominant toxins detected in $A$. tamarense were C1, 2 and GTX1, 4. GTX2, 3, C3, and neoSTX were also detected, but STX was absent. During the feeding experiments, the toxin profile of oysters changed substantially, showing marked differences from that of the supplid dinoflagellate. The most notable difference was the change in the relative amounts of C2, GTX1, 4 and neoSTX. In the toxic bivalves, the amount of $\mathrm{C} 2$, which is dominant in $A$. tamarense, decreased from 30.0 to $2.4 \mathrm{~mol} \%$ after only two days. The proportion of GTX1 in oysters increased almost linearly, though slowly, for 8 days, attaining a maximum of $51.3 \mathrm{~mol} \%$. In contrast, GTX 4 decreased rapidly from 34.2 to $20.8 \mathrm{~mol} \%$ in first two days, and its content thereafter remained relatively constant (20.8 to 22.4 mol\%). A small amount of STX appeared in the oysters after day 6 of feeding. In addition, the proportion of neoSTX (14.7-40.0 mol\%) was much higher than that in A. tamarense $(4.5 \mathrm{~mol} \%)$. These differences have been partly explained by the chemical and/or enzymatic transformation of toxins after accumulation in bivalve tissues ${ }^{10), 19)}$. Anderson et al. pointed out that selective uptake and release of toxins in bivalves is another potential cause of the difference in toxin profiles between infested bivalves and the causative dinoflagellates ${ }^{20}$. As for the configuration of 11hydroxysulfate, PSP components in the strain of ATHS92 exist almost exclusively as $\beta$-epimers (GTX3, 4, C2, 4 ), which account for $66.3 \mathrm{~mol} \%$ of the total. This contrasts with the oysters, where $\beta$-epimers represent 24.8 , $29.8,25.1,27.3$ and $25.2 \mathrm{~mol} \%$ of the total after $2,4,6,8$ and 10 days of feeding, respectively. This indicates that PSP components exist in the form of the chemically more stable $\alpha$-epimers in the oysters. According to many previous reports, including ours, epimerization between $\alpha$ and $\beta$-epimers appears to take place readily through spontaneous equilibration in response to changes in the intracellular environment of bivalves. Chen et al. reported rapid transformation of GTX4 to GTX1 in purple clams, Hiatula rostrata, fed with the toxic dinoflagellate A. minutum ${ }^{21)}$. Oshima et al. reported rapid degradation of N-1 hydroxy toxins and conversion of $11 \beta$-hydroxysulfate to the $11 \alpha$-epimer during the accumulation process in scallops, mussels and oysters ${ }^{7}$. Murakami et al. reported that the ratio of $\alpha$-epimer (GTX1) to $\beta$-epimer (GTX4) at C11 tended to increase up to the equilibrium point of $3: 1$ in PSPinfested bivalves from Ibaraki Prefecture ${ }^{13}$. In this study, the rate of GTX1 increase in oyster was estimated to be about $3.99 \mathrm{~mol} \%$ per day. It is noteworthy that this rate is much lower than the rate of $19.85 \mathrm{~mol} \%$ per day in the case of short-necked clam ${ }^{6)}$. This result indicates that there are great differences in the rate of conversion from GTX4 to GTX1 among bivalves. On the other hand, the contents of GTX2, 3 remained comparatively constant during the experiment, suggesting that the stability of $\beta$-epimers differs for each PSP component.

It seems that enzymatic processes are involved in the transformation of GTXs to STX through the reductive elimination of C-11 hydroxysulfate and N-1 hydroxyl moieties ${ }^{12)}$. Although the process of OH-GTX reduction is not understood in detail, natural reductants such as glutathione and cysteine appear to be responsible for this reduction of GTX to $\mathrm{STX}^{19), 22)}$. Kotaki et al. reported the bioconversion of GTX1-3 to STX through reductive elimination of the $\mathrm{N}-1 \mathrm{OH}$ and $\mathrm{C}-11$ $\mathrm{OSO}_{3}$ groups of GTXs by two species of bacteria, Pseudomonas sp. and Vibrio sp., isolated from the viscera of crabs and the turban shell ${ }^{23)}$.

Several previous studies have indicated that bivalves have lower proportions of $N$-sulfocarbamoyl toxins (C1, 2) and higher proportions of carbamate toxins (GTX14) than those of the ingested toxigenic dinoflagellates. Noguchi et al. reported a possible bioconversion process from low-toxicity components such as $\mathrm{C} 1$, 2 to high-toxicity ones, based on the results of feeding experiments $^{24)}$. C1, 2 in $A$. catenella were hardly found in mussels, and they gave a higher toxicity level than that expected from the uptake of $A$. catenella cells. With regard to transformation of $N$-sulfocarbamoyl toxins in 
bivalves, the presence of carbamoylase, which catalyzes hydrolysis of the carbamoyl (or $N$-sulfocarbamoyl) moiety of PSP, was first recognized in the little-necked clam Protothaca staminea ${ }^{25)}$. A carbamoylase was also purified from the digestive glands of the Japanese clam Mactra chinensis ${ }^{26)}$.

In the seawater in which oysters had been reared, two unknown components (UK1, 2) was recognized along with GTX2, 3 in GTX analysis, whereas none of C1, 2, 3, neoSTX and STX was detected. The retention times of UK1, 2 were 11.26 and $14.63 \mathrm{~min}$, respectively. It seems that these components were derived from metabolic products formed within the shellfish tissues and excreted through the shellfish kidneys.

Results obtained in this study suggest that extremely complex mechanisms, including selective accumulation of toxins, chemical and/or enzymatic degradation or transformation and bacterial conversion, might be involved in the development of shellfish toxicity.

\section{References}

1) Murakami, R., Noguchi, T., Paralytic shellfish poison. J. Food Hyg. Soc. Japan, 41, 1-10 (2000).

2) Shimizu, Y., Recent progress in marine toxin research. Pure \& Appl. Chem., 54, 1,973-1,980 (1982).

3) Asakawa, M., Miyazawa, K., Noguchi, T., Studies on paralytic shellfish poison (PSP) toxification of bivalves in association with appearance of Alexandrium tamarense, in Hiroshima Bay, Hiroshima Prefecture. J. Food Hyg. Soc. Japan, 34, 50-54 (1993).

4) Asakawa, M., Miyazawa, K., Takayama, H., Noguchi, T., Dinoflagellate Alexandrium tamarense as the source of paralytic shellfish poison (PSP) contained in bivalves from Hiroshima Bay, Hiroshima Prefecture, Japan. Toxicon, 33, 691-697 (1995).

5) Asakawa, M., Takayama, H., Beppu, R., Miyazawa, K., Occurrence of paralytic shellfish poison (PSP)-producing dinoflagellates Alexandrium tamarense in Hiroshima Bay, Hiroshima Prefecture, Japan during 1993-2004 and its PSP profiles. J. Food Hyg. Soc. Japan, 46, 246-250 (2005).

6) Asakawa, M., Beppu, R., Tsubota, M., Ito, K., Takayama, H., Miyazawa, K., Paralytic shellfish poison (PSP)-profiles and toxification of short-necked clams fed with toxic dinoflagellates Alexandrium tamarense. J. Food Hyg. Soc. Japan, 46, 251-255 (2005).

7) Oshima, Y., Sugino, K., Itakura, H., Hirota, M., Yasumoto, T., "Comparative studies on paralytic shellfish toxin profile of dinoflagellates and bivalves", Toxic Marine Phytoplankton, Graneli, E., Sundstrom, B., Edler, L., Anderson, D., eds., New York: Elsevier, 1990, p. 391-396.

8) Jeon, J. K., Han, M. S., Lee, H. O., "Paralytic shellfish toxins in the mussels and Alexandrium tamarense (dinoflagellate) from Gamraepo, Korea in 1989”, Harmful and Toxic Algal Blooms, UNESCO, Yasumoto, T., Oshima, Y., Fukuyo, Y., eds., Sendai, 1996, p. 65-68.

9) Suzuki, T., Yamasaki, M., Ota, H., Comparison of paralytic shellfish toxin profiles between the scallop Patinopecten yessoensis and the mussel Mytilus galloprovincialis. Fish. Sci., 64, 850-851 (1998).

10) Shimizu, Y., Yoshioka, M., Transformation of paralytic shellfish toxins as demonstrated in scallop homogenates. Science, 212, 547-549 (1981).
11) Sullivan, J. J., Iwaoka, W. T., Liston, J., Enzymatic transformation of PSP toxins in the littleneck clam (Protothaca staminea). Biochem. Biophys. Res. Commun., 114, 465-472 (1983).

12) Murakami, R., Yamamoto, K., Noguchi, T., Difference in PSP composition among various parts of surf clam. J. Food Hyg. Soc. Japan, 40, 55-61 (1999).

13) Murakami, R., Yamamoto, K., Noguchi, T., Toxicity and paralytic shellfish poison composition of three species of bivalves collected in Ibaraki Prefecture, Japan. J. Food Hyg. Soc. Japan, 40, 46-54 (1999).

14) Life Health Bureau, Ministry of Health and Welfare of Japan ed., "Shokuhin Eisei Kensa Shishin" p. 300-305 (1991), Japan Food Hygiene Association, Tokyo.

15) Noguchi, T., Murakami, R., "PSP (Paralytic shellfish poison)", Kaidoku no nazo, Noguchi, T., Murakami, R., eds., Tokyo: Seizando, 2004, p. 23-38.

16) Bricelj, V. M., Lee, J. H., Cembella, A. D., Influence of dinoflagellate cell toxicity on uptake and loss of paralytic shellfish toxins in the northern quahog Mercenaria mercenaria. Mar. Ecol. Prog. Ser., 74, 33-46 (1991).

17) Sekiguchi, K., Sato, S., Ogata, T., Kaga, S., Kodama, M., Accumulation and depuration kinetics of paralytic shellfish toxins in the scallop Patinopecten yessoensis fed Alexandrium tamarense. Mar. Ecol. Prog. Ser., 220, 213218 (2001)

18) Suzuki, T., Ichimi, K., Oshima, Y., Kamiyama, T., Paralytic shellfish poisoning (PSP) toxin profiles and short-term detoxification kinetics in mussels Mytilus galloprovincialis fed with the toxic dinoflagellate Alexandrium tamarense. Harmful Algae, 2, 201-206 (2003).

19) Oshima, Y., "Chemical and enzymatic transformation of paralytic shellfish toxins in marine organisms", Harmful Marine Algal Blooms, Lassus, P., Arzul. G., Erard, E., Gentien, P., Marcaillou, C., eds., Paris: Elsevier, 1995, p. 475-480.

20) Anderson, D. M., "Toxin variability in Alexandrium species", Toxic Marine Phytoplankton, Graneli, E., Sundstrom, B., Edler, L. and Anderson, D., eds., New York: Elsevier, 1990, p. 41-51.

21) Chen, C. Y., Chou, H. N., Fate of paralytic shellfish poisoning toxins in purple clam Hiatula rostrata, in outdoor culture and laboratory culture. Mar. Poll. Bull., 44, 733738 (2002)

22) Asakawa, M., Takagi, M., Iida, A., Oishi, K., Studies on conversion of paralytic shellfish poison (PSP) components by biochemical agents. Eisei Kagaku, 33, 50-55 (1987).

23) Kotaki, Y., Oshima, Y., Yasumoto, T., Bacterial transformation of paralytic shellfish toxins in coral reef crabs and a marine snail. Bull. Japan. Soc. Sci. Fish., 51, 1,0091,013 (1985).

24) Noguchi, T., Maruyama, J., Onoue, Y., Hashimoto, K., Ikeda, T., Toxins of mussels infested with Protogonyaulax catenella isolated from Senzaki Bay, Yamaguchi Prefecture. Nippon Suis. Gakk., 48, 499 (1983).

25) Sullivan, J. J., Iwaoka, W. T., Liston, J., Enzymatic transformation of PSP toxins in the littleneck clam (Protothaca staminea). Biochem. Biophys. Res. Commun., 144, 465-472 (1983).

26) Lin, H. P., Cho, Y., Yashiro, H., Yamada, T., Oshima, Y., Purification and characterization of paralytic shellfish toxin transforming enzyme from Mactra chinensis. Toxicon, 44, 657-668 (2004). 